\title{
Effect of Daniellia oliveri leaf meal in total mixed rations on the performance of Savannah Brown goats
}

${ }^{1}$ Suleiman, A. O., ${ }^{2}$ Alemede, I. C., ${ }^{2}$ Aremu, A., ${ }^{*}$ Olafadehan ${ }^{3}$ O. A. and ${ }^{4}$ Muftau, M. A. ${ }^{1}$ Department of Animal Health and Production, Faculty of Veterinary Medicine, University of Abuja, Nigeria

${ }^{2}$ Department of Animal Production, School of Agriculture and Agricultural Technology, Federal University of Technology, Minna, Nigeria

${ }^{3}$ Department of Animal Science, Faculty of Agriculture, University of Abuja, Nigeria ${ }^{4}$ Department of Animal Science, Faculty of Agriculture, Kebbi State University of Science and Technology, Aliero, Nigeria.

"Corresponding author: oaolafadehan@yahoo.com

\section{Abstract}

The study was carried out to determine the effect of Daniellia oliveri leaf meal (DOLM) in complete diets on feed intake, digestibility, nitrogen utilization and growth of Savannah Brown goats in a 90-day trial using the completely randomized design. Thirty-six does, with an average initial weight of $10.66 \mathrm{~kg}$, were randomly divided into four groups of similar body weight $(B W)$ and allocated to one of the four complete diets with DOLM inclusion levels at $0 \%, 20 \%, 30 \%$ and $40 \%$ respectively. Intakes of dry matter (DM) and organic matter (OM), and cost $/ \mathrm{kg} B W$ gain were higher $(p<0.05)$ in the control diet than in the treatment diets. Intake of crude protein $(C P)$ was higher $(p<0.05)$ for the control diet compared to the 30 and $40 \%$ DOLM diets. Feed conversion ratio and faecal nitrogen excretion of animals on $20 \%$ DOLM diet were lower $(p<0.05)$ than other diets. Final body weight, total weight gain and average daily weight gain were not ( $p>0.05$ ) affected by the diets. Digestibility of DM and $C P$, and nitrogen balance of animals on 0 and $20 \%$ DOLM diets were higher than those on 30 and $40 \%$ DOLM. Digestibility of OM and crude fibre was lowest $(p<0.05)$ for the control diet relative to other diets. Nitrogen intakes (NI) of 0 and $40 \%$ DOLM diets were lower $(p<0.05)$ compared to those of 20 and 30\% DOLM diets. Nitrogen absorbed (NA) and nitrogen retention (as \% of NA) were marginal $(p<0.05$ ) for $30 \%$ DOLM diet relative to other diets. Nitrogen retention (as \% of NI) was highest and lowest ( $p<0.05)$ for $20 \%$ DOLM diet, and 30 and $40 \%$ DOLM diets respectively. The study shows that Daniellia oliveri leaf meal can be used up to $40 \%$ inclusion level to replace 100\% of maize offal in the diet of Savannah Brown goats without adversely affecting the performance of the animals.

Keywords: Daniellia oliveri, growth, digestibility, nitrogen utilization, goats

\section{Introduction}

Intensive small ruminant production in Nigeria is affected by the increased cost of concentrate feedstuffs. The cost of concentrate feedstuffs is not only prohibitive but they are not readily available during certain periods of the year. This scenario has led to the search for alternative feed resources over the past few decades.
The potentials of browse fodders in overcoming this problem have been recognized (Okoli et al., 2002; Olafadehan et al., 2015; Olafadehan and Okunade, 2016).

Tropical trees and shrubs are an important component of the fodder resources for livestock and wildlife. The ability of their foliages to remain green and maintain 
their crude protein $(\mathrm{CP})$ content makes them potential sources of protein and energy (Olafadehan, 2013). The fodder value of their leaves and fruits are often superior to herbaceous plants, particularly in the case of legumes (Fadiyimu et al., 2011). The scarcity and soaring cost of conventional protein feedstuffs necessitate research into alternative resources for sustainable ruminant production. Use of browse legumes as supplement could help to alleviate the problem of dry season feeding of ruminants and equally reduce high cost of feeding associated with the use of conventional protein feeds (Olafadehan, 2013). In arid and semiarid zones, browse fodders provide the largest part of the protein supply during the driest months. For example, it is estimated that in the Sahel up to $80 \%$ of the protein ration is provided by plants of the Capparaceae family during the three driest months of the year (Baumer, 2011). Afzelia africana, Ficus thonningii and Daniellia oliveri are examples of such browses used for this purpose.

Daniellia oliveri (Rolfe) leaves are cut by Fulani cattle herders for their animals which they eat with relish, especially during the dry season when grasses are scarce. In the work of Walden (1986) and Atta-krah and Reynolds (1989), the fodder value of Daniellia forage base on palatability, intake and digestibility is reported to be high, with $16.5 \%$ of crude protein. The objective of this study was to evaluate the effect of feeding varying levels of Daniellia oliveri leaf meal in complete diets on the performance characteristics of Savannah Brown goats.

Materials and Methods

Experimental location and preparation of test ingredient

The experiment was carried out at Halima
Farm, a private goat farm, located in Gwagwalada Local Government Area of the Federal Capital Territory. Leaf samples from both young and old trees of the experimental plant were harvested from various stands in February. They were cleaned, packed in the Kraft paper and cured under the shade for six days. The leaves were separated from the stalk after drying, milled to produce Daniellia oliveri leaf meal (DOLM), packed in sacks and stored until they were ready for use.

\section{Experimental animals and management}

Thirty six nulliparous Savannah Brown does of 5 to 6 months old, with an average initial body weight (BW) of $10.66 \mathrm{~kg}$, were used for the study. The animals were divided into four treatment groups of three replicates, with three animals per replicate, and were assigned randomly to one of four dietary treatments in a completely randomized design. Animals in each group had similar mean initial BW. The treatments consisted of four iso-nitrogenous total mixed diets containing DOLM at 0, 20, 30 and $40 \%$. The animals were fed at $3 \%$ body weight twice daily at $0800 \mathrm{~h}$ and $1600 \mathrm{~h}$ for a period of 12 weeks. Fresh clean water was provided ad libitum. Before the experiment commenced, the animals were vaccinated against Peste De Peste Ruminants (PPR) and given long acting oxytetracycline as prophylaxis against bacterial infection thrice at two days interval.

Digestibility and nitrogen balance studies Digestibility and nitrogen balance studies were carried out immediately after the feeding and growth trials. Three goats were randomly selected per treatment and transferred to metabolism crates for faecal and urinary samples collection. They were allowed 10 days adjustment to the crates before the commencement of the data collection for 7 days. The goats were kept in individual metabolic crate and feed offered, 
feed rejected, faeces and urine excreted were recorded daily. About $10 \%$ of total faecal and urinary output respectively were saved, pooled over the 7-day collection period and sub-sampled for each goat to produce representative samples for chemical analysis. Few drops of $10 \%$ sulphuric acid were used to trap the ammonia in the urine.

\section{Chemical analysis}

The proximate composition of the experimental diets and faeces and nitrogen content of the urine was carried out according to the methods of AOAC (2000). Condensed tannins (CT) concentration of DOLM was determined by the methods of Makkar(2003).

\section{Economic analysis}

Cost $/ \mathrm{kg}$ of diet was calculated by multiplying the prevailing unit cost price of each ingredient by the quantity used in the ration and dividing the summation of the total cost by $100 \mathrm{~kg}$. Cost $/ \mathrm{kg} \mathrm{BW}$ gain was calculated by multiplying the feed conversion ratio value with cost of feed $/ \mathrm{kg}$.

\section{Statistical analysis}

Data were analysed based on the completely randomized design using SAS (2000) package. Where significant, means were separated using Duncan's multiple range test. Signi? cance was declared at a level of $\mathrm{p} \leq 0.05$.

\section{Results and Discussion}

Whereas both crude fibre and metabolizable energy increased as the level of DOLM in the diets increased, the reverse was the case for ether extract which decreased with increasing level of the test ingredient in the diets (Table 1). The organic matter (OM) did not follow a particular trend. The high crude protein (CP) content of DOLM is consistent with previous report on this browse fodder (Okunade et al., 2014; Olafadehan and Okunade, 2016) and is suggestive of its potential as a supplement to low quality roughages. The CP levels of DOLM and the experimental diets were higher than the recommended level $(11-13 \%)$ for growing goats (Kearl, 1982).

Table 1: Ingredient and chemical composition of experimental diets

\begin{tabular}{|c|c|c|c|c|c|}
\hline \multirow[t]{2}{*}{ Ingredient } & \multicolumn{4}{|c|}{$\begin{array}{l}\text { Inclusion level of D. oliveri leaf meal } \\
(\%)\end{array}$} & \multirow[t]{2}{*}{ DOLM } \\
\hline & 0 & 20 & 30 & 40 & \\
\hline Maize & 23.5 & 26.5 & 27.5 & 29.5 & \\
\hline Cowpea husk & 21.0 & 20.0 & 21.0 & 21.0 & \\
\hline Groundnut cake & 12.0 & 10.0 & 8.00 & 6.00 & \\
\hline Maize offal & 40.0 & 20.0 & 10.0 & 0.0 & \\
\hline Daniellia oliveri leaf meal & 0.00 & 20.0 & 30.00 & 40.0 & \\
\hline Bone meal & 2.00 & 2.00 & 2.00 & 2.00 & \\
\hline Salt & 0.50 & 0.50 & 0.50 & 0.50 & \\
\hline Mineral-vitamin premix ${ }^{*}$ & 1.00 & 1.00 & 1.00 & 1.00 & \\
\hline Total & 100 & 100 & 100 & 100 & \\
\hline \multicolumn{6}{|l|}{ Analysed content $(\%)$} \\
\hline Dry matter & 94.20 & 94.40 & 94.60 & 95.10 & 96.90 \\
\hline Crude protein $(\% \mathrm{DM})$ & 17.10 & 17.29 & 17.44 & 17.36 & 19.68 \\
\hline Crude fibre $(\% \mathrm{DM})$ & 11.10 & 24.40 & 28.00 & 32.11 & 34.43 \\
\hline Ether extract (\% DM) & 14.40 & 13.03 & 12.01 & 10.34 & 9.11 \\
\hline Organic matter (\% DM) & 92.92 & 90.87 & 91.04 & 90.05 & 93.84 \\
\hline $\operatorname{Ash}(\% \mathrm{DM})$ & 7.08 & 9.13 & 8.96 & 9.95 & 6.16 \\
\hline Condensed tannins (\% DM) & ND & 0.90 & 1.35 & 1.80 & 4.50 \\
\hline $\mathrm{ME}(\mathrm{Kcal} / \mathrm{kg} \mathrm{DM})^{* *}$ & 2664 & 2736 & 2768 & 2808 & 2564 \\
\hline
\end{tabular}


Effect of Daniellia oliveri leaf meal on the performance of goats

Table 2: Feed intake and performance characteristics of doelings fed $D$.oliveri leaf meal in total mixed rations

\begin{tabular}{|c|c|c|c|c|c|}
\hline \multirow[t]{2}{*}{ Intake (g/d) } & \multicolumn{4}{|c|}{ Inclusion level of D. oliveri leaf meal (\%) } & \multirow[t]{2}{*}{ SEM } \\
\hline & $\mathbf{0}$ & 20 & 30 & 40 & \\
\hline Dry matter & $384.20^{\mathrm{a}}$ & $320.60^{b}$ & $315.40^{\mathrm{b}}$ & $300.60^{b}$ & 13.88 \\
\hline Organic matter & $363.40^{\mathrm{a}}$ & $300.50^{\mathrm{b}}$ & $310.30^{\mathrm{b}}$ & $290.60^{c}$ & 10.18 \\
\hline Crude protein & $100.17^{\mathrm{a}}$ & $102.06^{\mathrm{ab}}$ & $94.56^{\mathrm{b}}$ & $89.81^{\mathrm{b}}$ & 1.79 \\
\hline \multicolumn{6}{|l|}{ Growth performance } \\
\hline Initial body weight $(\mathrm{kg})$ & 10.71 & 10.79 & 10.52 & 10.65 & 0.43 \\
\hline Final body weight (kg) & 15.53 & 15.21 & 14.43 & 14.40 & 0.55 \\
\hline Total gain $(\mathrm{kg})$ & 4.82 & 4.42 & 3.91 & 3.75 & 0.10 \\
\hline Average daily gain (g) & 57.38 & 52.61 & 46.54 & 44.64 & 9.10 \\
\hline Feed conversion ratio & $6.70^{\mathrm{a}}$ & $6.09^{b}$ & $6.78^{\mathrm{a}}$ & $6.73^{\mathrm{a}}$ & 0.32 \\
\hline Cost/kgweight gain ( & 52.90 & 50.68 & 49.50 & 48.30 & \\
\hline Cost/kg BW gain & $354.43^{\mathrm{a}}$ & $308.64^{\mathrm{d}}$ & $335.61^{\mathrm{b}}$ & $325.06^{\mathrm{c}}$ & 4.50 \\
\hline
\end{tabular}

${ }^{\mathrm{abc}}$ Means with different superscripts in the same row are significantly different $(\mathrm{p}<0.05)$

The results of the feed intake and performance characteristics of the experimental goats are presented in Table 2. The DM intake of the goats fed the control diet was higher $(p<0.05)$ than that of the goats fed DOLM based diets which had similar DM intake. Lower feed intake of goats fed the DOLM based diets may be attributed to their higher fibre contents relative to the control diet. Fibre has been reported to result in gut fill and slow down the rate of passage of the digesta through the gastro-intestinal tract due to its bulkiness (Okunade et al., 2014; Olafadehan et al., 2014a). Similarly, the CT of DOLM may also be responsible for reduced DM intake by goats fed the DOLM based diets. Tannins have been reported to reduce feed palatability and consumption due to its astringent property (Olafadehan et al., 2014a). The result agrees with previous findings (Olafadehan et al., 2014a) who reported an inverse relationship between feed intake and dietary fibre level and CT respectively. The DM intake was lower than intake range of $433-443 \mathrm{~g} / \mathrm{d}$ reported for the same breed of goat fed graded levels of Gmelina arborea leaf meal in complete diets (Abdu et al., 2013). Lower intake in the current study could be due to sex effect, as doelings were used compared to most studies that used bucklings. Intake of OM was higher $(\mathrm{p}<0.05)$ for $0 \%$ DOLM than for DOLM based diets and among the DOLM diets, OM intake was lower $(p<0.05)$ for $40 \%$ DOLM than for 20 and 30\% DOLM which were not $(p>0.05)$ different. Consumption of $\mathrm{CP}$ was higher for the control diet compared to 30 and $40 \%$ DOLM. Lower CP and OM intakes of the DOLM diets are obviously due to lower feed intake by goats on the diets. Olafadehan et al. (2014b) earlier opined that nutrient intake is a function of feed intake ceteris paribus. Though average daily gain declined with increasing level of DOLM in the diets, there was no difference between the control and the DOLM diets. This suggests that DOLM was well utilized by the goats and DOLM can be fed up to $40 \%$ in a practical goat ration without any negative effect on the body weight of the goats. Feed conversion ratio was significantly $(p<0.05)$ lower for $20 \%$ DOLM compared to the other treatment groups. The result shows that goats fed $20 \%$ DOLM diet efficiently utilized their diet better than goats on other diets because they consumed less amount of feed per $\mathrm{kg}$ of weight gain. This result underlines the 
nutritive value of DOLM in goat diet. The cost $/ \mathrm{kg}$ gain of the control diet was higher $(p<0.05)$ than that of $40 \%$ DOLM indicating that $40 \%$ DOLM inclusion rate was a more economically viable diet than the control diet. This further justifies the feeding potential of DOLM in goat diets. The apparent nutrient digestibility of Savannah Brown does fed varying levels of Daniellia oliveri leaf meal is presented in Table 3.The DM and CP digestibility of the control and 20\% DOLM diets was higher $(\mathrm{p}<0.05)$ than that of $30 \%$ and $40 \%$ DOLM diets. However, there were no significant $(\mathrm{p}>0.05)$ differences between DM and CP digestibility of the control and 20\% DOLM, and $30 \%$ and $40 \%$ DOLM. Lower digestibility of DOLM at higher inclusion levels could be due to higher fibre contents of the diets, in agreement with previous reports (Olafadehan, 2013; Isah et al., 2015; Olafadehan and Adebayo, 2016). Both OM and CF digestibility were lower $(\mathrm{p}<0.05)$ in the control diet compared to DOLM diets. Increasing CF digestibility with increased level of DOLM in the diets suggests that the fibre levels of DOLM diets were lower than the threshold level at which dietary fibre inhibits digestibility.

Nitrogen utilization of doelings fed diets containing varying levels of DOLM is presented in Table 4. The nitrogen intakes of the control and the 40\% DOLM groups were $(p<0.05)$ greater compared to the nitrogen intakes of $20 \%$ and $30 \%$ DOLM groups. There was no significant difference $(p>0.05)$ in the urinary nitrogen excretion among the treatments. The faecal nitrogen of the 20\% DOLM group was marginal $(\mathrm{p}>0.05)$ relative to that of the control, $30 \%$ and 40\% DOLM diets. Nitrogen balance declined $(p<0.05)$ with the increasing level of DOLM, with 30 and 40\% DOLM having the lowest values. Lower nitrogen balance and nitrogen retention (as \% of nitrogen intake) at higher levels of DOLM inclusion

Table 3: Apparent digestibility of doelings fed $D$. oliveri leaf meal in total mixed rations

\begin{tabular}{llllll}
\hline Item (\%) & \multicolumn{2}{l}{ Inclusion level of D. oliveri leaf meal (\%) } & SEM \\
\cline { 2 - 5 } & $\mathbf{0}$ & $\mathbf{2 0}$ & $\mathbf{3 0}$ & $\mathbf{4 0}$ & \\
\hline Dry matter & $86.90^{\mathrm{a}}$ & $83.70^{\mathrm{a}}$ & $86.60^{\mathrm{b}}$ & $85.40^{\mathrm{b}}$ & 3.08 \\
Organic matter & $64.04^{\mathrm{c}}$ & $70.50^{\mathrm{b}}$ & $76.70^{\mathrm{a}}$ & $70.00^{\mathrm{b}}$ & 4.40 \\
Crude protein & $63.30^{\mathrm{a}}$ & $63.10^{\mathrm{a}}$ & $56.70^{\mathrm{b}}$ & $53.70^{\mathrm{b}}$ & 6.66 \\
Crude fibre & $33.50^{\mathrm{c}}$ & $44.10^{\mathrm{b}}$ & $51.30^{\mathrm{a}}$ & $55.35^{\mathrm{a}}$ & 2.63 \\
\hline
\end{tabular}

${ }^{\text {abc Means with different superscripts in the same row are significantly different }(p<0.05)}$

Table 4: Nitrogen balance of doelings fed $D$. Oliveri leaf meal in total mixed rations

\begin{tabular}{llllll}
\hline Variable (g/d) & \multicolumn{2}{l}{ Inclusion level of D. oliveri leaf meal (\%) } & \multicolumn{1}{c}{ SEM } \\
\cline { 2 - 5 } & $\mathbf{0}$ & $\mathbf{2 0}$ & $\mathbf{3 0}$ & $\mathbf{4 0}$ & \\
\hline Nitrogen intake & $52.30^{\mathrm{a}}$ & $48.80^{\mathrm{b}}$ & $45.85^{\mathrm{b}}$ & $50.35^{\mathrm{a}}$ & 9.28 \\
Faecal nitrogen & $20.22^{\mathrm{a}}$ & $15.50^{\mathrm{b}}$ & $20.80^{\mathrm{a}}$ & $20.50^{\mathrm{a}}$ & 1.61 \\
Urinary nitrogen & 11.30 & 12.90 & 13.90 & 10.50 & 1.05 \\
Nitrogen absorbed & $32.08^{\mathrm{a}}$ & $33.30^{\mathrm{a}}$ & $25.05^{\mathrm{c}}$ & $29.85^{\mathrm{b}}$ & 4.05 \\
Nitrogen balance & $20.78^{\mathrm{a}}$ & $20.40^{\mathrm{a}}$ & $11.15^{\mathrm{b}}$ & $10.35^{\mathrm{b}}$ & 2.69 \\
N retention & & & & & \\
$\quad \%$ of N intake & $39.73^{\mathrm{b}}$ & $41.80^{\mathrm{a}}$ & $24.32^{\mathrm{c}}$ & $20.55^{\mathrm{c}}$ & 8.45 \\
$\quad \%$ of N absorbed & $61.34^{\mathrm{ab}}$ & $68.24^{\mathrm{a}}$ & $54.63^{\mathrm{c}}$ & $59.29^{\mathrm{b}}$ & 11.00 \\
\hline
\end{tabular}

${ }^{\mathrm{abc}}$ Means with different superscripts on the same row are significantly different $(\mathrm{p}<0.05)$ 
Effect of Daniellia oliveri leaf meal on the performance of goats

may be due to the effect of the CT of DOLM which must have been more concentrated as the DOLM inclusion level increased. Tannins have been reported to have pronounced effect on nitrogen utilization of goats fed tannin-rich fodders (Olafadehan, 2013, Olafadehan et al., 2016). Higher nitrogen retention (as \% of $\mathrm{N}$ intake and \% of $\mathrm{N}$ absorbed) of $20 \%$ DOLM is indicative of the fact that the diet promoted better nitrogen utilization. It appears the tannin level of the $20 \%$ DOLM diet was more beneficial than the tannin concentrations of higher levels of DOLM (30 and 40\% DOLM). It is, however, pertinent so say that the better $\mathrm{N}$ utilization of the control and $20 \%$ DOLM diets did not result in pronounced average daily gain compared to 30 and $40 \%$ DOLM. The results imply that goats can tolerate up to $40 \%$ DOLM inclusion level without any negative effect on their growth performance. Olafadehan and Okunade (2016) had earlier demonstrated the impressive fodder value of Daniellia oliveri forage in goat nutrition.

\section{Conclusion and Recommendation}

The results of the study show the nutritive value of DOLM as a suitable fodder in goat nutrition. Inclusion of DOLM at $40 \%$ in a total mixed ration did not compromise the performance of the experimental goats but reduced the feed cost $/ \mathrm{kg} \mathrm{BW}$ gain. Daniellia oliveri leaves can be used as a fodder resource for intensive ruminant production.

\section{References}

Abdu, S. B., Hassan, M. R., Adamu, H. Y., Yashim, S. M. and Oketona, G. F. 2013. Nutrient intake and digestibility of Red Sokoto bucks fed varying levels of Gmelina (Gmelinaarborea) leaf meal. Nigerian Journal of Animal
Science 15: 125-133.

AOAC 2000. Official Methods of Analysis. $17^{\text {th }}$ ed. Association of Official Analytical Chemists, Washington, DC.

Atta-Krah, A. N. and Reynolds, L. 1989. Utilization of pasture and fodder shrubs in the nutrition of sheep and goats in the humid tropics of West Africa. In: Timon, V.M. and Baber, R.P. (eds.), Sheep and Goat Meat Production in the Humid Tropics of West Africa, FAO, Rome pp. 68-91.

Baumer, M. 2011. Legume and other fodder trees as protein sources for livestock. Produced by Agriculture and Consumer Protection. Food and Agricultural Organization. Corporate Document Repository.

Fadiyimu, A. A., Fajemisin, A. N. and Alokan, J. A. 2011. Chemical composition of some selected browse plants and their aceptability by West Afrcan dwarf sheep. Livestock Research for Rural Development 23(12). http://www.lrrd.org/ lrrd23/12/fadi23256. htm

Isah, O. A., Okunade, S. A., Aderinboye, R. Y. and Olafadehan, O. A. 2015. Effect of browse plant foliage supplementation on the performance of buckling goats fed threshed sorghum top basal diet. Tropical Animal Health and Production 47(6): 1027-1032.

Kearl, L. C. 1982. Nutrient Requirements of Ruminants in Developing Countries. Utah Agricultural Experimental Station, Utah State University, International Foodstuffs Institute, Logan, USA, pp. 59-69. 
Makkar, H. P. S. 2003. In: Makkar, H.P.S. (Ed.), Quantification of Tannins in Tree and Shrub Foliage. Kluwer Academic Publishers, p. 102.

Okoli, I. C., Ebere, C. S., Uchegbu, M. C., Uddah, C. A. and Ibeaewuchi, I. I. 2002. Survey of the diversity of plants utilized for small ruminant feeding in south eastern Nigeria. Agriculture Ecosystem and Environment 45(6): 2529.

Okunade, S. A., Olafadehan, O. A., Isah, O. A. 2014. Fodder potential and acceptability of selected tree leaves by goats. Animal Nutrition and Feed Technology 14: 489-498

Olafadehan, O. A. 2013. Feeding value of Pterocarpus erinaceus for growing goats. Animal Feed Science Technology 185: 1-8.

Olafadehan, O. A. Adewumi, M. K. and Okunade, S. A. 2014a. Effects of feeding tannin-containing forage in varying proportion with concentrate on the voluntary intake, haematological and biochemical indices of goats. Trakia Journal of Sciences 12(1): 7381.

Olafadehan, O. A., Okunade, S. A. and Njidda, A. A. 2014b. Evaluation of bovine rumen content as a feed for lambs. Tropical Animal Health and Production 46: 939-945.

Olafadehan, O. A., Okunade, S. A., Njidda, A. A., Adewumi, M. K., Sunday, U. E. and Sarah, S. 2015. Feed intake, digestibility, nitrogen utilization and ruminal fermentation characteristics of Red Sokoto goats fed concentrate partially replaced with Piliostigma thonningii foliage.
Tropical Animal Production Investigations 18(2): 39-47.

Olafadehan, O. A. and Okunade, S. A. 2016. Fodder value of three browse forage species for growing goats. Journal of the Saudi Society of Agricultural Sciences. http://dx.doi.org/10.1016/j.jssas.2016 .01 .001 (In press).

Olafadehan, O. A. and Adebayo, O. F. 2016. Nutritional evaluation of ammoniated threshed sorghum top as a feed for growing goats. Tropical Animal Health and Production48(4): 785-791.

Olafadehan, O. A., Njidda, A. A., Okunade, S. A., Adewumi, M. K., Awosanmi, K. J., Ijanmi, T. and Raymond, A. 2016. Effects of varying forage: concentrate ratio on performance and ruminal fermentation in growing goats. Animal Nutrition Feed Technology 16:373-382.

Pauzenga, U. 1985. Feeding parent-stock. Journal of Zoo Technical International 19:22-23.

SAS, 2000. SAS/STAT Users Guide, Version 8.1 ed. SAS Institute Inc., Cary, NC, USA.

Walden, J. H. 1986. Trees in forage systems. In: Kang, B.T. and Reynolds, L. (eds.), Alley Farming in the Humid and Sub-humid Tropics. IDRC-271e, Ottawa, Canada, pp. 71-81.

Received: $24^{\text {th }}$ September, 2016 Accepted: 23 ${ }^{\text {rd }}$ February, 2017 